\title{
Consumers Behaviours and Attitudes towards Safe Vegetables Production in Ghana: A Case Study of the Cities of Kumasi and Cape Coast
}

\author{
Acheampong, P. P. ${ }^{1}$, Braimah, H. ${ }^{2}$, Ankomah-Danso, A. ${ }^{3}$, Mochiah, M. B. ${ }^{4}$ \\ ${ }^{1}$ Department of Socioeconomics, Crops Research Institute, P.O. Box 3785, Kumasi, Ghana \\ ${ }^{2}$ Department of plant health, Crops Research Institute, P.O. Box 3785, Kumasi, Ghana \\ ${ }^{3}$ Department of Biometrics, Crops Research Institute, P.O. Box 3785, Kumasi, Ghana \\ ${ }^{4}$ Department of plant health, P.O. Box 3785, Crops Research Institute, Kumasi, Ghana.
}

ACCEPTED 6th August, 2012

\begin{abstract}
Vegetables are either cultivated conventionally using a full complement of agrochemicals particularly pesticides or with very little or none or using only organic where they are said to be cultivated organically. In the developed economies these differences are acknowledged and attract different prices. In many developing countries such as Ghana, there are no clear cut differences between organic (safe) and inorganic vegetables. One hundred and ninety four consumers from two cities in Ghana were interviewed through structured questionnaires to ascertain their perceptions, purchasing behaviour and willingness to pay for safe vegetables. The results indicated that $55.2 \%$ of consumers were unaware of safe/organic vegetables. Also majority of consumers (59.8\%) purchased vegetables if they looked fresh. The ordinary vegetable consumer could not distinguish between safe (organic) and inorganic vegetables in the market. An Ordered Probit Model was used to assess the factors that would influence consumers' willingness to pay higher prices for safe vegetables. The model showed that labeling, visual appearance, freshness and availability had significant influences on consumers' willingness to pay higher prices for safe vegetables. The study provided valuable information on consumers' perceptions and willingness to pay a higher price for safe vegetables.

We Therefore recommend the development and implementation of segregating indicators and separate distribution channels for organic and inorganic vegetables in Ghana.
\end{abstract}

KEYWORDS: organic, safe, labeling, freshness, ordered Probit model, chemical residue, conventional vegetable

\section{INTRODUCTION}

In several African cities, about $50-90 \%$ of fresh vegetables are supplied from urban and peri-urban production systems (Cofie et al., 2003). Limited availability of refrigerated transport and cool storage in Sub-Saharran Africa makes urban and peri-urban vegetable production particularly important in the supply of fresh foods. This is similar for most developing countries where urban agriculture provides a critical livelihood and a source of food for low income households (Scott et al., 2004; Drechsel et al., 2002). Urban and periurban agricultural activity offers jobs for the poor, especially women and is an effective way to overcome poverty (Cofie et al. 2003; Ravallion et al., 2007). In Ghana, the production and marketing of vegetables provides employment for many people especially in the dry season (Obuobie et al., 2006). It also makes significant contributions to livelihoods and food security. For example, around Kumasi, more than 12,000 smallholder farmers are involved in vegetable farming during the dry seasons (Cornish et al. 2001) and urban farmers grow 90\% of the main vegetables eaten in the cities of Ghana (Danso et al., 2003). In their effort to grow a good crop, urban and peri-urban vegetable producers resort to various practices including the use of inappropriate pesticides that often compromise the safety of the produce. Consumers on the other hand are increasingly becoming more and more concerned about the safety of the food and food products that they purchase and consume. Schifferstein and Oude Ophuis (1998) reported that this concern goes together with their awareness of the relation between the production practice and quality of food products. The increased awareness of the importance of a healthy diet and positive perception of fruits and vegetable has contributed to increasing demand of vegetables, especially for organic vegetables (Lambert, 2001). Wier et al., (2003), in their study on behaviour and attitudes of the organic fruit consumers concluded that health hazards were the main motivation for purchase of organic and pesticide free fruits. Consumer 
confidence in vegetable consumption is dwindling as many consumers become aware of the unhealthy practices employed for production of conventional vegetables and the health risks associated with the consumption of their products. Studies conducted in Ghana (Oboubi et al., 2006), found that vegetables produced in and around peri-urban centers had residues such as chemical deposits and faecal coli forms.

This study was conducted as part of a collaborative initiative amongst four West African countries; Ghana, Benin, Burkina Faso and Senegal. It was aimed at ascertaining farmers' and consumers' awareness and perceptions on production and consumption of organic vegetables. It was also aimed at coaching them on how to produce and or obtain and consume safe vegetables. Much attention was paid to the use of chemical pesticides in vegetable production and the presence of chemical residues on vegetables and vegetable products. It also set out to provide data for production of safe vegetables in West Africa. In doing this the study assessed the general knowledge and perceptions of consumers about safe vegetables and determined the market potential for their production in Ghana. This paper provides information on consumers' perceptions, purchasing behaviour and willingness to pay for safe vegetables in the cities of Kumasi and Cape Coast in Ghana.

\section{Methodology}

Two hundred consumers were interviewed using structured questionnaires in the capital cities of two regions of Ghana in September 2009. The numbers of consumers interviewed were equal for the two regions $(n=100$ from the Ashanti region and $n=100$ from the Central region). These regions were selected based on their importance in vegetables

Questionnaires were administered by face to face contact to 200 consumers living in and around Kumasi and Cape Coast. The level of awareness for risk in vegetable consumption among respondents was determined by asking them about their willingness to pay higher prices for safe vegetables. Demographic variables collected including respondents' age, level of education, household size and marital status were also collected. Data were also collected on attributes of the vegetables such as accessibility, freshness, colour, appearance, certification and packaging. production, their cultural diversity and the ease of market accessibility. Kumasi, the capital city of the Ashanti region has a semi-humid tropical climate and lies in the tropical forest zone, with an annual average rainfall of about $1420 \mathrm{~mm}$. The rainfall pattern is bimodal with a major season falling between March and July and a minor one occurring from September to November. On the other hand Cape Coast, the capital city of the Central Region lies within the coastal savannah zone. The rainfall pattern here is similar to that of Ashanti region. However, the zone is drier with an annual mean precipitation of about $1250 \mathrm{~mm}$. The mean monthly temperatures for both regions range from $24^{\circ} \mathrm{C}$ to $27^{\circ} \mathrm{C}$.

\section{Data collection and analysis}

The questionnaire were administered to selected consumers based on their' access to markets. Thus in the two regions two centers each were selected per region, giving a total of four centers for the study. Two hundred consumers were randomly selected from all the four centers, making sure that an average of fifty consumers were selected for each of the centers. Six questionnaires were discarded due to inability to complete them, leaving 194 questionnaires for the analysis.

The questionnaires were structured to ascertain the degree of agreement of respondents to a particular statement based on a 5 point scale of acceptance of the statement. The responses ranged from strongly agree (1), agree (2), somewhat agree (3), weakly agree (4) to very weakly agree (5) based on their perception and evaluation of the topic or issue raised. Some questions posed were designed to determine a "yes"/ "no" or "none" response about the attitude of respondents towards organic vegetables.

The Ordered Probit Model (Pindyck and Rubinfeld, 1991) was used to estimate the effects of both quantitative and qualitative variables on consumers' willingness to pay higher prices for safer vegetables. The selection of the methodology was informed by the dichotomous nature of the dependent variable (consumer willingness to pay a higher price for organic vegetables). The model that adequately satisfies the criterion falls within the group of models of qualitative choices, more specifically the probit regression.

How to Cite this Article: Acheampong, P. P. , Braimah, H. , Ankomah-Danso, A. , Mochiah, M. B."Consumers Behaviours and Attitudes towards Safe Vegetables Production in Ghana: A Case Study of the Cities of Kumasi and Cape Coast ," Science Journal of Agricultural Research and Management, Volume 2012, Article ID sjarm-109, 11 Pages, 2012. doi:10.7237/sjarm/109 
Following from the work of Greene (1997), the ordered probit model can be specified as built around a latent regression:

$$
y_{i}^{*}=\beta \mathrm{X}^{*}{ }_{i}+\Sigma
$$

Where $y^{*}{ }_{i}$ is constant, $\beta$ is the vector of unknown parameters and $X_{i}$ is a vector of explanatory variables (which may be continuous or discrete) denoting attributes influencing willingness to pay a higher price for safe vegetables in Ghana and $\Sigma$ being the independently and identically normally distributed error term. The ordered probit model tests the null hypothesis $\mathrm{H}_{0}$ : $\beta \mathrm{X}=0$ for every explanatory variable denoting that the independent variable $X$ does not have an effect on the explanation of changes in the probability of $y$.

The empirical model of the effect of explanatory variables on the consumer willingness to pay a higher price for safe vegetables is specified using the following linear relationship:

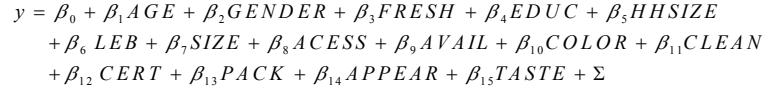

Where ${ }^{y}$ is the dependent variable which is the willingness to pay higher price for safe vegetables and it takes the value of 1 if the consumer is willing to pay and 0 if he/she is not willing to pay, $\beta_{0}$ is the constant, $\beta_{1}-\beta_{15}$ the coefficients, AGE of consumer in years, Gender of consumer (dummy; 1:female,0:male), EDUC formal education (dummy; 1: formal education,0: no formal education), HHSIZE household size and it is the number of members in a house that share the same food, LEB the labeling is the classification of vegetables (Dummy; 1:organic ,0: conventional), SIZE the weight of the vegetables in kilogrammes, ACCESS the access of the consumer to a vegetable market (dummy;1:accessible,0: not accessible), AVAIL the availability of vegetables (dummy ; 1 : available, 0: not available), COLOR the colour of the vegetable, CERT the official recognition by a Certifying agency with its tag, PACK the packaging of the vegetable, APPAR the appearance or form of the vegetable, TASTE the flavor or feel of the vegetable to the palate and $\Sigma$ is the error term. The coefficients of the regression model were estimated using maximum likelihood estimation technique.

\section{Results}

\section{Consumers' Demographic status}

Seventy one percent of the consumers interviewed were females and $29 \%$ were males. The respondents were fairly youthful, with $34.0 \%$ between the ages of 18 -25years, $20.1 \%$ between the ages of 36 year and 45 years, $9.8 \%$ between the ages of 46 years and 55years and only 2.1\% between the ages of 56 years and 65 years. The respondents were almost equally divided in marital status. While $47.4 \%$ were married, $45.9 \%$ were single, $5.2 \%$ were divorced and $1.5 \%$ were widowed. Ninety three percent of the respondents had formal education. For example while $54.6 \%$ of the respondents had basic level education, 20.1\% had secondary education and $15.5 \%$ had tertiary level education, $2.6 \%$ had vocational education and only $7.2 \%$ had no formal education. The average size of the respondents' household was about 5 with a mean of 2 children per household.

\section{Consumption patterns of vegetables and frequency of purchase}

In order to ascertain consumers' knowledge on the organic and inorganic vegetables, respondents were asked to indicate the either organic or conventional type of vegetable they regularly consumed in their households. While $36.6 \%$ stated that they consumed organic vegetables, $30.4 \%$ indicated that they consumed conventional vegetables and $33.0 \%$ could not determine the type of vegetables they consumed. (table1). Most respondents (88.7\%) purchased and consumed vegetables daily (Table 1). Consumers purchased vegetables from various places but mostly the market (96.4\%). On the question of attributes used in purchasing vegetables majority (59.8\%) used freshness as an important attribute, $17.5 \%$ used cleanness vegetables as important attribute and 4.6\%, 6.7\%, 9.3\%, and 2.1\% used good taste, absence of perforations, attractive colour and storability of vegetables respectively as important attributes that affected their purchasing decision(Table.1).

How to Cite this Article: Acheampong, P. P. , Braimah, H. , Ankomah-Danso, A. , Mochiah, M. B."Consumers Behaviours and Attitudes towards Safe Vegetables Production in Ghana: A Case Study of the Cities of Kumasi and Cape Coast ," Science Journal of Agricultural Research and Management, Volume 2012, Article ID sjarm-109, 11 Pages, 2012. doi:10.7237/sjarm/109 
Table 1. Consumption patterns and frequency of purchase of vegetables

\begin{tabular}{ccc}
\hline & Numbers of respondents & Percent of respondents \\
\hline Types of vegetables consumed & 71 & 36.6 \\
Organic & 59 & 30.4 \\
Conventional & 64 & 33.0 \\
Don't know & 172 & \\
Frequency of consumption of vegetables & 8 & 88.7 \\
Everyday & 4 & 4.1 \\
Once a week & 7 & 2.1 \\
Two times in a week & 3 & 3.6 \\
Three times in a week & & 1.5 \\
Four times in a week & 187 & \\
Place of purchasing vegetables & 4 & 96.4 \\
Market & 1 & 2.1 \\
own farm & 2 & 0.5 \\
farm gate & & 1.0 \\
Other (hawkers) & 116 & \\
Fresh & 34 & 59.8 \\
Clean & 9 & 17.5 \\
Good taste & 13 & 4.6 \\
Important attributes when purchasing vegetables & 18 & 6.7 \\
Attractive color & 4 & 9.3 \\
Storability & & 2.1 \\
\hline
\end{tabular}

\section{Consumers' awareness of pesticide use on vegetables}

Consumers' knowledge about crop management practices especially the use of pesticides in vegetable production was tested. The sources of information of respondents with regards to safe vegetables were determined. While $33 \%, 24.2 \%$ and $8.8 \%$ mentioned television, radio and written journals respectively as their sources of information, twenty three percent got their information from hospitals, schools and neighbours. Unfortunately, as many as $11.3 \%$ of the respondents had no information about good and or safe vegetables (Table 2). Many respondents had no idea how vegetables were produced. Out of the 194 consumers interviewed as many as 129 (66.5\%) had no knowledge of any producer and only 65 $(33.5 \%)$ knew any producers. Majority $(70.1 \%)$ of consumers had no knowledge of how vegetable producers controlled vegetable pests and diseases. Twenty four percent of consumers knew farmers used chemicals to control their pests and 5.7\% knew that some farmers used organic control methods. The consumers who knew about the methods farmers applied to control their pests and diseases had been associated with such producers and had witnessed some of their operations.

These statistics notwithstanding, only $44.8 \%$ consumers were aware the consumption of contaminated vegetables caused any diseases, while $55.2 \%$ were ignorant of any such risks (Table 2). Some of ignorant consumers could not understand how vegetables could cause diseases since vegetables supply good nutrients to the body. The contaminants of concern to the enlightened consumers were chemical residues (29.4\%), worm eggs $(23.2 \%)$, fungi $(16.5 \%)$ and human feaces (9.8\%). A good proportion of this group $(21.1 \%)$ were however unable to mention any contaminants of concern (table 2). Vegetables cultivated in urban and peri-urban Ghana are irrigated mostly with contaminated water. Most water bodies in and

How to Cite this Article: Acheampong, P. P. , Braimah, H. , Ankomah-Danso, A. , Mochiah, M. B.“Consumers Behaviours and Attitudes towards Safe Vegetables Production in Ghana: A Case Study of the Cities of Kumasi and Cape Coast," Science Journal of Agricultural Research and Management, Volume 2012, Article ID sjarm-109, 11 Pages, 2012. doi:10.7237/sjarm/109 
around urban areas are contaminated with household liquid and solid waste as well as factory and other industrial wastes. Indiscriminate use of pesticides in the cultivation of vegetables is also of great concern to consumers as most of them lamented about chemical residues.

Pest control measures acceptable to consumers were explored. Most consumers (57.2\%) were of the opinion that appropriate use of pesticides was not detrimental to human well being. Others $(22.7 \%)$ intimated that the adoption of good agronomic practices in vegetable production could keep pests and diseases in check. A small proportion $(3.1 \%)$ of consumers thought that the adoption of organic farming practices could avert the development of pest and diseases on vegetables. The use of woodash according to some consumers (5.2\%) prevented insects from attacking vegetables and thus reduced their impact on vegetables. Most of the people interviewed who had back yard gardens used wood ash to control insect pests (Table 2). About twelve percent could not suggest any option for vegetables diseases management as they expressed complete ignorance about pest management practices in vegetable production (Table2).

Table 2. Percent of consumers on knowledge of pesticide use by farmers

\begin{tabular}{ccc}
\hline Parameter tested & Numbers of respondents & Percent of respondents \\
\hline Information source of safe vegetables & & \\
Television & 64 & 33.0 \\
Written journal & 17 & 8.8 \\
Radio & 47 & 24.2 \\
Others & 44 & 22.7 \\
Don't know & 22 & 11.3 \\
contaminants of concern & & \\
Chemical residue & 57 & 29.4 \\
Human faeces & 19 & 9.8 \\
Fungi on vegetables & 32 & 16.5 \\
Worms eggs & 45 & 23.2 \\
Don't know & 41 & 21.1 \\
Chemical control & & \\
Costs Control measures acceptable to consumers & 111 & 57.2 \\
Good agronomic practices & 44 & 22.7 \\
Organic manure applications & 6 & 3.1 \\
Don't know & 23 & 11.9 \\
Awareness about safe vegetables & & \\
Aware & 87 & 44.8 \\
Unaware & 107 & 55.2 \\
\hline
\end{tabular}

\section{Consumers purchasing behaviour}

The general behaviour of consumers on purchasing vegetables was determined by the use of a five point level of agreements. Whether the consumer agreed with a statement and the level of agreement or disagreement with the statement showed his/her behaviour at purchasing vegetables. On the statement 'I always negotiate a cheaper price when shopping for vegetables', about $31 \%$ of the consumers disagreed with that while almost $20 \%$ weakly agreed, 12.37 fairly agreed, $22.16 \%$ agreed and $14.43 \%$ strongly agreed (Table 3 ). Contrary to the popular social dictates of negotiating for prices to be reduced, quite a sizeable proportion of the consumer interviewed indicated that they would pay for vegetables at prices quoted by retailers. Quite a sizeable number of consumers (31\%) indicated that they would not negotiate for a cheaper price as pertains to popular view, but they would rather pay for the price as quoted by retailers. When consumers were asked to react to

How to Cite this Article: Acheampong, P. P. , Braimah, H. , Ankomah-Danso, A. , Mochiah, M. B."Consumers Behaviours and Attitudes towards Safe Vegetables Production in Ghana: A Case Study of the Cities of Kumasi and Cape Coast ," Science Journal of Agricultural Research and Management, Volume 2012, Article ID sjarm-109, 11 Pages, 2012. doi:10.7237/sjarm/109 
the statement that 'vegetable prices normally reflect quality', $40.20 \%$ very weakly agreed , $23.71 \%$ moderately agreed, 16.49\% weakly agreed, 9.27\% agreed and only $10.31 \%$ strongly agreed with the statement (Table 3). These results suggested that respondents in the survey areas did not believe that quality was necessarily reflected in price. Thus the general view that the higher the price of a product the better the quality, was found to be untrue with vegetable consumers in the study areas.
When the general price preferences of consumers for safe vegetables were sought, most of the consumers opted for average price for safe vegetables. Many (43.3\%) of consumers said they would prefer to buy safe vegetables at an average price, $33 \%$ said they would want safe vegetables to be cheap and $23.7 \%$ would not mind a high price for safe vegetables (Table 3 ).

Table 3. Estimated levels of consumer agreement with predetermined statements on purchasing behavior

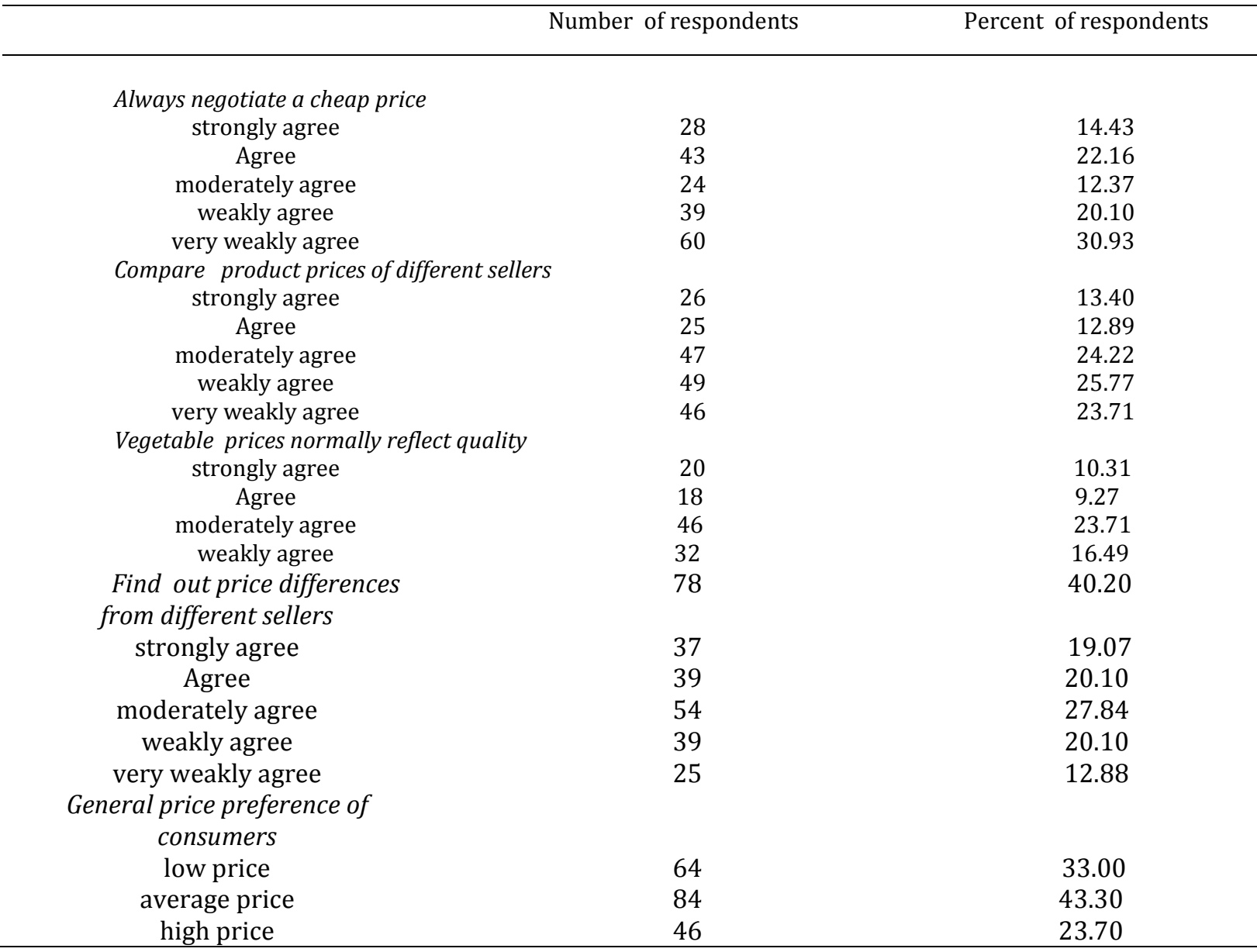

In an attempt to decipher the behaviours of consumers to various issues relating to their purchasing decisions and relationships with vegetable sellers predetermined questions were posed. When quizzed on whether they usually found fresh vegetables with their dealers, 'about 35\% strongly agreed that their dealers usually sold them fresh and tasty vegetables, $21.13 \%$ agreed and only $8.24 \%$ very weakly agreed (Table 4 ). To the

statement 'I complain to my dealer whenever vegetables taste bad', 34.02\% agreed strongly that they did. Also to the question if vegetables were of bad quality whether they changed their dealer', $31.95 \%$ strongly agreed that they would change their dealers if the quality of vegetables were bad.

How to Cite this Article: Acheampong, P. P. , Braimah, H. , Ankomah-Danso, A. , Mochiah, M. B.“Consumers Behaviours and Attitudes towards Safe Vegetables Production in Ghana: A Case Study of the Cities of Kumasi and Cape Coast," Science Journal of Agricultural Research and Management, Volume 2012, Article ID sjarm-109, 11 Pages, 2012. doi:10.7237/sjarm/109 
There was a general perception among consumers in the study that when vegetables were fresh, they were of good quality and therefore they expected only fresh vegetables from their dealers.

On the determination of the long term relationships between retailers and consumers it was found that 'only $24.74 \%$ strongly agreed with the statement they usually kept trust with their dealer and bought vegetables regularly from the same dealer while $22.68 \%$ very weakly agreed. Indeed $26.28 \%$ strongly agreed that they personally knew their dealers whilst $21.13 \%$ said they bought vegetables from different places and thus from different sellers (Table 5). It was established during the study that consumers bought their vegetables from different markets and so maintaining one dealer was not practical as some dealers are only present in markets occasionally. In Ghana vegetables are sold either in the market and street corners by fixed retailers or by mobile retailers (hawkers) who roam about the community with their wares and usually sell what vegetables are in season.

Table 4. Estimated levels of consumers agreement with predetermined statements on customer loyalty

\begin{tabular}{|c|c|c|}
\hline & Number of respondents & Percent of respondents \\
\hline \multicolumn{3}{|c|}{ Usually find fresh and tasty vegetables from my dealer } \\
\hline Strongly agree & 67 & 34.54 \\
\hline Agree & 41 & 21.13 \\
\hline Moderately agree & 43 & 22.16 \\
\hline Weakly agree & 27 & 13.92 \\
\hline Very weakly agree & 16 & 8.24 \\
\hline \multicolumn{3}{|c|}{ Complain to dealer when vegetables taste bad } \\
\hline Strongly agree & 66 & 34.02 \\
\hline Agree & 30 & 15.46 \\
\hline Moderately agree & 38 & 19.59 \\
\hline Weakly agree & 40 & 20.62 \\
\hline Very weakly agree & 20 & 10.31 \\
\hline \multicolumn{3}{|c|}{ Change dealer if vegetables are of poor quality } \\
\hline Strongly agree & 62 & 31.95 \\
\hline Agree & 27 & 13.91 \\
\hline Moderately agree & 58 & 29.89 \\
\hline Weakly agree & 23 & 11.86 \\
\hline Very weakly agree & 24 & 11.85 \\
\hline \multicolumn{3}{|c|}{ Buy vegetable from the same buyer } \\
\hline Strongly Agree & 47 & 24.74 \\
\hline Agree & 33 & 17.01 \\
\hline Moderately Agree & 39 & 20.10 \\
\hline Weakly Agree & 30 & 15.46 \\
\hline Very Weakly Agree & 44 & 22.68 \\
\hline \multicolumn{3}{|l|}{ Know Seller Personally } \\
\hline Strongly Agree & 51 & 26.28 \\
\hline Agree & 32 & 16.49 \\
\hline Modearately Agree & 26 & 13.4 \\
\hline Weakly Agree & 45 & 23.2 \\
\hline Very Weakly Agree & 40 & 20.62 \\
\hline \multicolumn{3}{|c|}{ Buy Vegetable from different place } \\
\hline Strongly agree & 41 & 21.13 \\
\hline Agree & 33 & 17.01 \\
\hline Moderately agree & 51 & 26.28 \\
\hline Weakly agree & 23 & 11.86 \\
\hline Very weakly agree & 46 & 23.71 \\
\hline
\end{tabular}

How to Cite this Article: Acheampong, P. P. , Braimah, H. , Ankomah-Danso, A. , Mochiah, M. B.“Consumers Behaviours and Attitudes towards Safe Vegetables Production in Ghana: A Case Study of the Cities of Kumasi and Cape Coast," Science Journal of Agricultural Research and Management, Volume 2012, Article ID sjarm-109, 11 Pages, 2012. doi:10.7237/sjarm/109 


\section{Factors affecting willingness to pay a higher price for safe vegetables}

From table 5, the most important factors influencing the willingness to pay a higher price for safe vegetables were appearance, availability, labeling, certification and freshness. Gender, though not significant had positive coefficient, indicating that males and females alike were more likely to pay higher prices for safe vegetables. The coefficient on formal education was positive but insignificant, indicating that literates were more likely to pay higher prices for safe vegetables. Household size also had positive but insignificant coefficient, also pointing to probable effect of household size on consumer willingness to pay a higher price for safe vegetables. Labeling had positive and significant coefficient. The consumers' ability to categorize different vegetables highly influenced their willingness to pay higher price for a preferred category. Size of vegetable showed a negative and insignificant indicating that smallness and or largeness of a vegetable would have no influence on the price consumers paid. The coefficient for taste was positive though insignificant, indicating that the flavour of a vegetable could influence the willingness to pay a higher price for safe vegetables. Appearance and availability had positive and significant coefficients demonstrating that they would very much influence the consumers' willingness to pay higher price for safe vegetables. Consumers were more willing to pay a higher price if the visual appearance of the vegetables was good and the vegetables were readily available. Incidentally, packaging, certification and accessibility had no impact on the willingness to pay a higher price for organic products as the coefficients were not significant. Unsurprisingly, freshness had a positive and highly significant coefficient showing its high influence on consumers' willingness to pay a higher price for safe vegetables.

Table 5. Probit estimations of willingness to pay higher price for safe vegetables

\begin{tabular}{cccc}
\hline Variables & Estimated coefficient & Standard error & Level of significance \\
\hline Constant & -3.47 & -1.78 & 0.06 \\
Gender & -0.46 & 0.34 & 0.17 \\
Age & 0.86 & 0.089 & 0.33 \\
Formal education & 0.024 & 0.29 & 0.934 \\
Household size & 0.003 & 0.53 & 0.94 \\
Labeling & $0.75^{* *}$ & 0.34 & 0.02 \\
Size & -0.04 & 0.55 & 0.93 \\
Taste & 0.59 & 0.59 & 0.31 \\
Appearance & $1.49^{*}$ & 0.79 & 0.059 \\
Accessibility & -0.14 & 0.70 & 0.83 \\
Availability & $1.25^{* *}$ & 0.54 & 0.02 \\
Packaging & 0.0231 & 0.06 & 0.955 \\
Certification & -0.709 & -1.29 & 0.196 \\
\hline
\end{tabular}

How to Cite this Article: Acheampong, P. P. , Braimah, H. , Ankomah-Danso, A. , Mochiah, M. B."Consumers Behaviours and Attitudes towards Safe Vegetables Production in Ghana: A Case Study of the Cities of Kumasi and Cape Coast," Science Journal of Agricultural Research and Management, Volume 2012, Article ID sjarm-109, 11 Pages, 2012. doi:10.7237/sjarm/109 


\begin{tabular}{|c|c|c|c|}
\hline Colour & -0.29 & -0.32 & 0.37 \\
\hline Freshness & $0.79 * * *$ & 0.29 & 0.012 \\
\hline Clean & 0.35 & 0.32 & 0.27 \\
\hline Log likelihood & -58.22 & & \\
\hline Wald $X^{2}$ & 66.7 & & \\
\hline Number of observations & 194 & & \\
\hline
\end{tabular}

${ }^{* * *}$ significant at $1 \%,{ }^{* *}$ significant at $<5 \%,{ }^{*}$ significant at $5 \%$

\section{Discussion}

More females (71\%) than males (29\%) were interviewed in the survey due to culture in selection, purchase and preparation of vegetables in most Ghanaian homes. Many males even though they were also consumers were reluctant to be interviewed because they felt they were not involved so much in the selection, purchasing and the preparation of vegetables in their household. In most parts of Ghana, food preparation is traditionally an all women's affair. Ninety three percent of respondents had formal education even though many females were interviewed. Ghana Human Development Report, (1998) and Scadding, (1989), confirmed that more women tend to have basic education reaching up to the junior high school level.

Consumers' ability to determine the category of vegetables consumed was mixed. It was difficult for consumers to tell whether they consumed organic or inorganic vegetables. Due to poor labeling culture, both organic and conventional vegetables are mixed up in the market place. It is therefore probable that even those who said they consumed organic vegetables were only speculating, with a high possibility that they were wrong in their assumption (table 1). It is generally difficult in Ghana to differentiate between two products of the same variety as a result of poor labeling culture and lack of clear cut identification criteria. Also, there are no specific designated places for the sale of the different categories of vegetables. However the consumption of vegetables is a daily affair and they are acquired from any available sources, usually with high consideration for availability, convenience and price. Many of the consumers admitted eating vegetables every day. Every household in Ghana incorporates either one local vegetable or another or some exotic vegetables in every meal prepared. There is hardly any food prepared and consumed without some vegetables being used. Tomatoes, peppers, onions and garden eggs are vegetables that one cannot do without in most locally prepared meals. These ties in with the report of Smith and Eyzaguirre (2007) that vegetables are part of the daily diets of most Africans.

Consumers judged the safety of vegetables on their appearances. They considered vegetables to be safe if they were fresh, clean and appeared pleasant to the eye (table1). Oboubie et al. (2006), had already reported that characteristics such as freshness, colour and spotless leaves were considered by consumers in Ghana when buying vegetables. Indeed in this study, consumers only used physical state of vegetables to classify them as good or bad, preferring fresh looking and spotlessly clean produce. Appearance had a positive and significant impact on the willingness to pay at $10 \%$ level. Consumers consider appearance when making purchasing decision. It is probably based on these preferences of consumers that producers engage in various practices to produce vegetables that please the market. Most often this involves the use of excessively high doses of agro-chemicals especially pesticides which are sometimes used in cocktails with little regard for the safety of themselves, the consumers or even the environment (Okello and Swinton, 2010). This demand for fresh and good looking produce is by no means limited to the Ghanaian consumer. Penau et al., (2006) and Sakagami et al., (2006), pointed out that freshness was an important consideration in purchasing vegetables and fruits in many countries.

Labeling was found to affect willingness to pay higher prices for vegetables. Respondents wanted to see labels showing differences between

How to Cite this Article: Acheampong, P. P. , Braimah, H. , Ankomah-Danso, A. , Mochiah, M. B.“Consumers Behaviours and Attitudes towards Safe Vegetables Production in Ghana: A Case Study of the Cities of Kumasi and Cape Coast," Science Journal of Agricultural Research and Management, Volume 2012, Article ID sjarm-109, 11 Pages, 2012. doi:10.7237/sjarm/109 
conventional and non-conventional vegetables. Earlier consumer studies suggested similarly that trustworthy labels guaranteeing organic production were very important requirements for consumers to purchase organic foods (Trijp et al., 1997; Sylvander, 1995).The lack of knowledge about vegetables production practices especially the amounts and types of agro-chemicals used was very evident in this study. More than $70 \%$ of respondents had no idea of how vegetables were produced. Yiridoe et al., (2005), saw this as a common phenomenon as vegetables are produced far from the sights of consumers. Consumers are therefore biased towards farmers' products (Jaffe and Gertler, 2006) and this might affect demand of vegetables. Nonetheless, respondents knew about contaminants such as human faeces, worm eggs, and chemical residue on vegetables (table 2). Many vegetables are produced using water contaminated with such materials (Obuobie et al., 2006).

Consumers behave normally in the market environment. They look for fresh, clean and tasty vegetables with reasonable prices. Thompson and Kidwell (1998), reported that taste, resembling that of home-grown produce and other quality considerations as important motivations for buying organic food. Most studies have shown that many buyers of organically produced vegetables accept as true that organic vegetables taste better than conventionally produced vegetables (Fillion and Arazi, 2002; Zhao et al., 2007) though sensory evaluation might have proven otherwise.

Availability of safe vegetables affected the willingness of consumer to pay higher prices for vegetables. The markets for organic vegetables in Ghana are insufficiently developed and therefore it is expected that availability will have influence on the willingness to pay for organic vegetables. This expectation is confirmed by the results of the model which indicate that a strong distribution strategy for organic vegetables should be developed to encourage supply. Similar studies by Nouhoheflin et al. (2004), found that availability affects willingness to pay for organic vegetables in Ghana and Benin.

\section{Conclusion}

This study provides valuable information on consumers' perceptions and willingness to pay a higher price for safe vegetables. The ordinary vegetable consumer could not distinguish between safe (organic) and inorganic vegetables in the market. The results give impetus to the development and implementation of segregating indicators and distribution channels between organic and inorganic vegetables. This would boost consumer confidence and facilitate the decision to choose one or the other. In addition, availability of organic vegetables was found to be a factor in willingness to pay a higher price for safe vegetables and provides an opportunity for promoting local production and a retail chain for organic vegetables. Even though many consumers indicated their preference of organic vegetables over conventional ones due to health concerns, they also considered the price as very important in purchasing the so called organic vegetables. It was however not clear whether this was anchored on the lack of price differences between conventional and organic vegetables and could change if they were confronted with competitive prices for organic vegetables.

\section{Acknowledgment}

We acknowledge the Austrian Development Agency (ADA) and International Institute of Tropical Agriculture (IITA) for providing funds for this study

\section{References}

1. Cofie 00, van Veenhuizen R, Drechsel P ( 2003). Contribution of urban and peri-urban agriculture to food security in Sub-Saharan Africa. Paper presented at the Africa Day of the 3rd WWF in Kyoto, 17-3-2003.

2. Cornish G A, Aidoo J B, Ayamba I ( 2001). Informal irrigation in the peri-urban zone of Kumasi, Ghana. An analysis of farmer activity and productivity. Report OD/TN 103,

3. Danso G, Drechsel P, Wiafe-Antwi T, Gyiele N, 2002a. Income of farming systems around Kumasi, Ghana. Urban Agriculture Magazine 7: 5-6.

4. Drechsel P, Blumenthal UJ, Keraita B ( 2002). Balancing health and livelihoods: Adjusting wastewater irrigation guidelines for resource-poor countries. Urban Agriculture Magazine 8: 7-9.

5. Fillion L, Arazi S (2002). Does organic food taste better? A claim substantiation approach. Nutrition and Food Science 32, 153-157.

6. Greene WH (1997). Econometric Analysis, 2nd ed. Pearson US Imports \& PHIPEs, 1000 pp.

7. Grunert K G, Bech-Larsen T, Bredahl L (2000). Ghana Human Development Report. 1998. In UNDP (1998) Human Development Report. Oxford: Oxford University Press.

How to Cite this Article: Acheampong, P. P. , Braimah, H. , Ankomah-Danso, A. , Mochiah, M. B."Consumers Behaviours and Attitudes towards Safe Vegetables Production in Ghana: A Case Study of the Cities of Kumasi and Cape Coast ," Science Journal of Agricultural Research and Management, Volume 2012, Article ID sjarm-109, 11 Pages, 2012. doi:10.7237/sjarm/109 
8. Jaffe J, Gertler M (2006). Victual vicissitudes: consumer deskilling and the (gendered) transformation of food systems. Agriculture and Human Values 23: 143-162.

9. Lambert N (2001). Food choice, Phitochemicals and Cancer Prevention. In: L. Frever, E. Risvik, H. Schifferstein (editors) Food, people and society - A European perspective of consumers' food choice. Springer -Verlag, Berlin, pp. 131154.

10. Nouhoheflin T, Coulibaly O, Cherry A J, Al-Hassan R Adegbola, P Y ( 2005).Consumer perceptions and willingness to pay for organic vegetable in Benin and Ghana . 2004 Inaugural Symposium , December 6-8,2004, Nairobi,Kenya 9525, African Association of agricultural Economists(AAAE)

11. Obuobie E, Keraita B, Danso G, Amoah P, Cofie 00, RaschidSally L, Drechsel P. (2006). Irrigated urban vegetable production in Ghana: Characteristics, benefits and risks. IWMI-RUAF-CPWF, Accra, Ghana: IWMI, 150 pp

12. Okello JJ, Swinton SW ( 2010). From circle of poison to circle of virtue: pesticides, export standards and Kenya's green bean farmers. Journal of Agricultural Economics, 61: 209-224

13. Penau S, Hoehn, E, Roth HR, Escher F, Nuessli J (2006). Importance and consumer perception of freshness of apples. Food Quality and Preference, 17:9-19.

14. Pindyck RS, Rubinfeld,DL (1991). Econometric models and economic forecasts. New York: McGraw-Hill Inc. 596 pp.

15. Ravallion M, Chen S, Sangraula P( 2007). New Evidence on the Urbanization of Global Poverty. Policy Research Working Paper 4199. World Bank, Washington, DC

16. Scott C A, Faruqui NI, Raschid-Sally L.(2004). Wastewater Use in Irrigated Agriculture: Confronting the Livelihood and Environmental Realities; IWMI-IDRCCABI, Wallingford, UK. 193 pp. www.idrc.ca/en/ev-31595-201-1-DO TOPIC.html

17. Scadding H (1989). Junior Secondary School - An Educational Initiative in Ghana. Compare, 19: 1, 43-48.

18. Schifferstein H N J, Oude Ophuis PAM (1998). Healthrelated determinants of organic food consumption in the Netherlands. Food Quality and Preference, 9,:119-133.

19. Sakagami M, Sato M, Ueta K ( 2006). Measuring consumer preferences regarding organic labelling and the JAS label in particular. New Zealand Journal of Agricultural Research, 49: 247-254.

20. Smith I F, Eyzaguirre P (2007). African Leafy Vegetables: The Role in the WHO Global Fruit and Vegetables Initiative. African Journal of Food, Agriculture, Nutrition and Development., 7; 3, 2007.

21. Sylvander B (1995). Conventions on Quality in the Fruit and Vegetables Sector: Results on the organic Sector. Acta Horticulture, 340: 241-246.

22. Thompson GD, Kidwell J (1998). Explaining the choice of organic produce: cosmetic defects, prices, and consumer preferences. American Journal of Agricultural Economics, 80: 277-287.

23. Trijp HCM, Steenkamp J-BEM, Candel MJJM (1997), Quality Labeling as Instrument to Create product Equity: The case of IKB in the Netherlands, Dordrecth: Kluwer Academic Publishers.

24. Wier M, Hansen LG, Andersen LM, Millock K (2003). Consumer preferences for organic foods. Organic Agriculture: Sustainability, Markets and Policies. CABI Publishing. 408 pp.

25. Yiridoe E, Bonti-Ankomah S, Ralph C ( 2005). Comparison of consumer perceptions and preference toward organic versus conventionally produced foods: a review and update of the literature. Renewable Agriculture and Food Systems, 20: 193-205.

26. Zhao X, Chambers E, Matta Z, Loughin T, Carey E ( 2007). Consumer sensory analysis of organically and conventionally grown vegetables. Journal of Food Science 72, 87-91.

How to Cite this Article: Acheampong, P. P. , Braimah, H. , Ankomah-Danso, A. , Mochiah, M. B.“Consumers Behaviours and Attitudes towards Safe Vegetables Production in Ghana: A Case Study of the Cities of Kumasi and Cape Coast," Science Journal of Agricultural Research and Management, Volume 2012, Article ID sjarm-109, 11 Pages, 2012. doi:10.7237/sjarm/109 